\title{
Petrology of Metaluminous A-Type Rhyolite Discovered from Hadjer el Hamis Volcanoes (Lake Chad Basin)
}

\author{
Claudial Amane Lagmet ${ }^{1}$, Fadimatou Ngounouno Yamgouot ${ }^{2}$, \\ Mama Ntoumbe $^{3}$, Abdou Aziz Youpougam ${ }^{3}$, Ismaïla Ngounouno ${ }^{3}$ \\ ${ }^{1}$ Institut Universitaire Polytechnique de Mongo, N’Djaména, Chad \\ ${ }^{2}$ Department of Earth Sciences, Faculty of Science, University of Ngaoundere, Yaounde, Cameroon \\ ${ }^{3}$ School of Geology and Mining Engineering, University of Ngaoundere, Meiganga, Cameroon \\ Email: mbowou2000@yahoo.fr
}

How to cite this paper: Lagmet, C.A., Yamgouot, F.N., Ntoumbe, M., Youpougam, A.A. and Ngounouno, I. (2018) Petrology of Metaluminous A-Type Rhyolite Discovered from Hadjer el Hamis Volcanoes (Lake Chad Basin). Open Journal of Geology, 8, 883-895.

https://doi.org/10.4236/ojg.2018.89052

Received: June 15, 2018

Accepted: August 17, 2018

Published: August 20, 2018

Copyright $\odot 2018$ by authors and Scientific Research Publishing Inc. This work is licensed under the Creative Commons Attribution International License (CC BY 4.0).

http://creativecommons.org/licenses/by/4.0/

\begin{abstract}
Metaluminous (P.I. > 1) rhyolite from Hadjer el Hamis consisted of quartz, alkali feldspar, clinopyroxene (hedenbergite), amphibole (F-arfvedsonite) and oxides-hydroxides (ilmenite, magnetite, limonite) phenocrysts is characterized by the negative $\mathrm{Eu}, \mathrm{Ba}, \mathrm{P}, \mathrm{Sr}$ and $\mathrm{Ti}$ anomalies. This metaluminous rhyolite and the early discovered peralkaline rhyolites in Hadjer el Hamis volcanoes derive likely from the same source, according to their coexistence on the same sector and their similar $\mathrm{Zr} / \mathrm{Nb}$ ratios. The causes of magma heterogeneity are likely linked to varying amounts of extraction of an earlier melt phase or tectonic juxtaposition or a sudden increasing of $\mathrm{O}_{2}$ in silicic magmas, triggered from a hydrothermal process, associated with $\mathrm{F}$ - and alkali-bearing fluids influx, which promoted the enrichment of $\mathrm{Na}$ in the hedenbergite rims and the crystallization of arfvedsonite.
\end{abstract}

\section{Keywords}

Metaluminous, Rhyolites, Lake Chad, Petrology, Hadjer el Hamis

\section{Introduction}

Metaluminous A-type rocks frequently occur in post-orogenic, extensional settings [1]. The rhyolitic outcrops of Hadjer el Hamis overhang the sedimentary units of the SE Lake Chad [2] (Figure 1). These rhyolites can be related to a tectonomagmatic stage, of the western central Africa rift system, which may constitute the $\mathrm{NNE}$ extension of a $\mathrm{N} 50^{\circ} \mathrm{E}$ to $\mathrm{N} 30^{\circ} \mathrm{E}$ elongated succession of small 


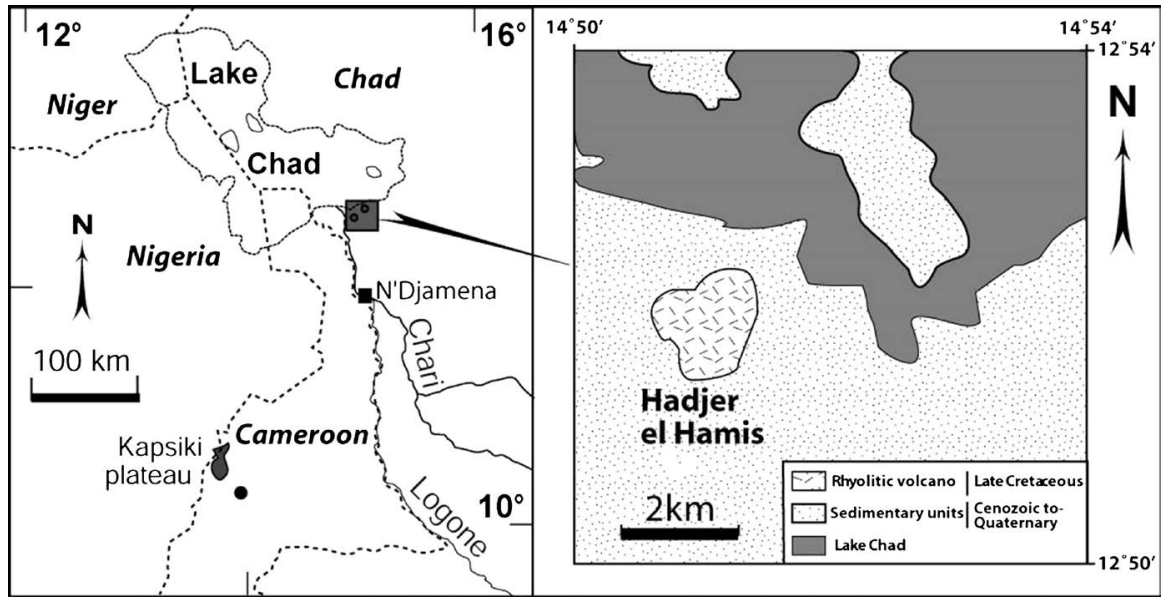

Figure 1. Location of the studied zone in the Lake Chad basin.

alkaline complexes, from the Gulf of Guinea to the Lake Chad [3].

The metaluminous A-type rocks were discovered from the Lake Chad basin. This paper adds to an earlier paper on the petrology of peralkaline rhyolites from the SE Lake Chad [4] which presents a fieldwork, petrographical study, mineralogical and geochemical data of the metaluminous rhyolites from Hadjer el Hamis (Lake Chad basin). Furthermore, we present the relationship between these peralkaline and metaluminous rhyolites.

\section{Geological Background and Fieldwork}

The metaluminous rhyolitic rocks, which are the focus of this paper, are mostly welded lavas. At the Late Cretaceous times, tectonic events would have led to the occurrence of the eruptive rocks in southeastern edge of Lake Chad [4]. The volcanic eruptions, which consisted mainly of rhyolites, were probably triggered after the reactivation of Precambrian basement faults [5].

The previous petrological studies of the rhyolites from the SE Lake Chad have mainly been concentrated on peralkaline-type, which are the predominant silicic volcanic rocks; and not to the coexisting aluminous and peralkaline rhyolites. Nowadays, the coexistence in the same domain of peralkaline and mertaluminous rocks is strongly debated in order to determine their genetic relationship [6].

Metaluminous rhyolites from the SE Lake Chad were sampled on rocky slopes and/or in working quarries at the flanks of Hadjer el Hamis volcanoes. Hadjer el Hamis (418 m a.s.l) are five domes or necks composed of both, dark green and grey rhyolites, showing vertical columnar jointing [4]. The rhyolitic fragments split from the flanks are scattered around the foothills.

\section{Analytical Methods}

The petrography of samples was determined by optical microscopy (OM) using an Olympus BX60 binocular microscope at the "Instituto de Geociências, Universidade de Brasília (Brazil)". The superprobe JEOL JXA-8230, Electron Probe Microanalyser of the same University was used for back-scattered electron (BSE) 
images, qualitative and quantitative analyses for the mineral phases (clinopyroxene, amphibole, feldspar, Fe-Ti oxides and hydroxides). The operating conditions included an accelerating voltage of $15 \mathrm{kV}$ and a probe current of $1.08 \times$ $10^{-8} \mathrm{~A}$ for elements. The counting times at the peaks were $60 \mathrm{~s}$ for $\mathrm{Zr}$, La and Ce; and $20 \mathrm{~s}$ for the other selected elements. The diameter of the electron beam was $10 \mu \mathrm{m}$. All data were corrected with standard ZAF correction procedures. Natural minerals and synthetic glasses were used as standards.

Whole-rock samples were crushed to fine powder in a "Siebtechnik" mill equipped with two agate jars at the "Instituto de Geociências, Universidade de Brasilia (Brazil)". Representative electron microprobe analyses of whole-rock major and trace elements analyses were performed using respectively ICP-ES and ICP-MS methods at the Acme Analytical Laboratories, Chile. Analytical detection limits (D.L) were less than $0.05 \mathrm{wt} \%$ for the major elements and less than $20 \mathrm{ppm}$ for the trace elements. The analysis for total carbon and sulfur were performed at the low analytical detection limits $(0.02 \mathrm{wt} \%)$. Total loss on ignition (L.O.I) was determined gravimetrically after heating or sintering at $1000^{\circ} \mathrm{C}$.

\section{Results}

\subsection{Nomenclature and Petrography}

The compositions of all the samples from Hadjer el Hamis fall within the rhyolite field in TAS diagram (Figure 2; [7]). The peralkaline index (P.I. = molar $\left.\left[\mathrm{Na}_{2} \mathrm{O}+\mathrm{K}_{2} \mathrm{O}\right] / \mathrm{Al}_{2} \mathrm{O}_{3}\right)$ is higher than unity for the peralkaline rhyolites and low for the metaluminous (Figure 3 ) rhyolites (P.I.: 0.95).

Rhyolites from Hadjer el Hamis are both, dark green (peralkaline) and grey (metaluminous), with abundant feldspar phenocrysts in a groundmass of fine-grained dark and light minerals. Indeed, samples are porphyritic with partly

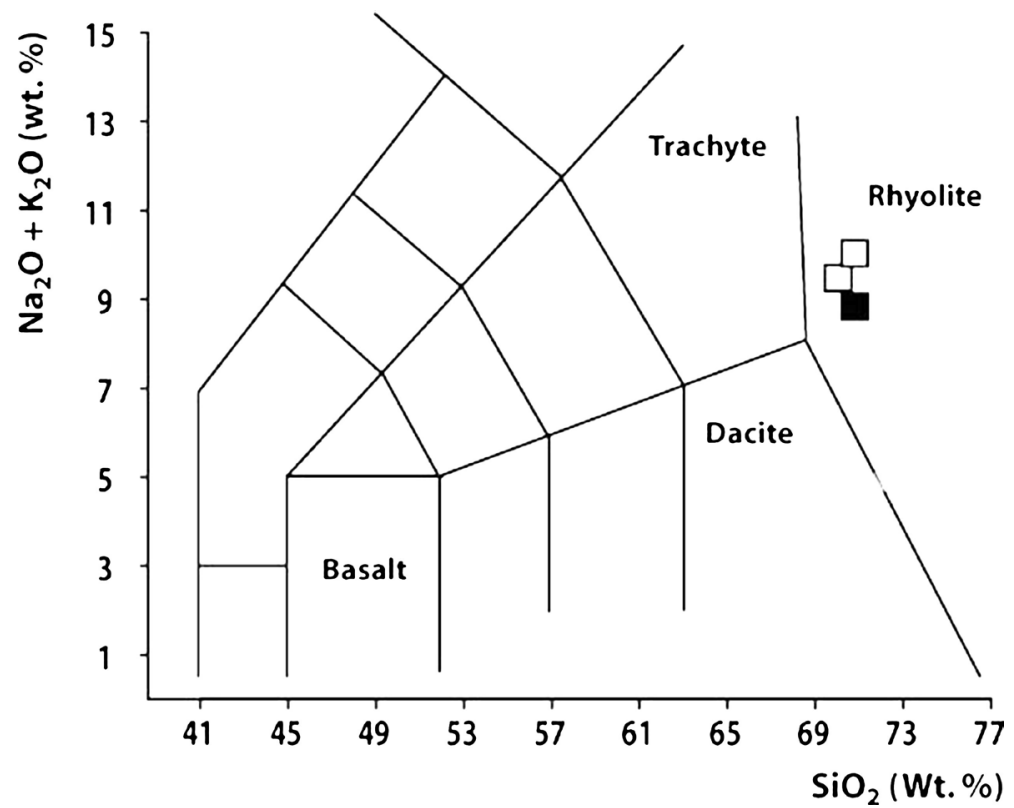

Figure 2. Total alkali-silica (TAS) diagram [7] for the rhyolites from Hadjer el Hamis. 


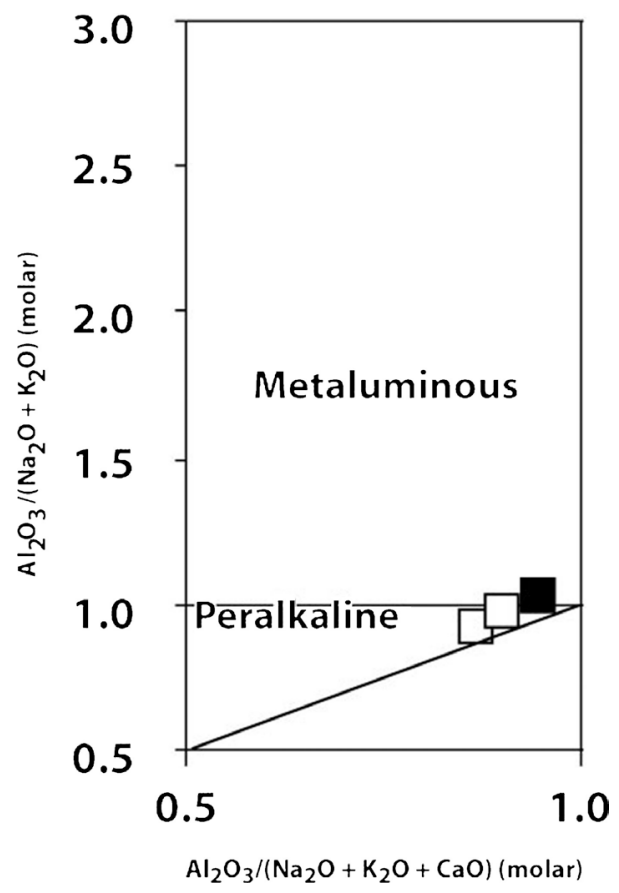

Figure 3. Diagram for discrimination of peralkaline and metaluminous rhyolites from Hadjer el Hamis.

fluidal groundmass, marked by the presence of oriented microlites.

Hadjer el Hamis metaluminous rhyolites contain phenocrysts of quartz (up to $1.5 \mathrm{~mm})$, alkali feldspar $(\sim 4.6 \mathrm{~mm})$, amphibole $(\sim 1.5 \mathrm{~mm})$, clinopyroxene $(\sim 1$ $\mathrm{mm})$ and Fe-Ti oxides $(\sim 1 \mathrm{~mm})$, scattered in the groundmass, consisting of alkali feldspar, amphibole and Fe-Ti oxides microlites, enclosed by a thin glassy phase.

This groundmass is very finely crystallized. Quartz phenocrysts are euhedral to subhedral, with corrosion gulfs. Euhedral and subhedral feldspar phenocrysts are irregular, colourless to yellow brown, with spongy structure. In the interstices left by these phenocrysts occur microlites of feldspar and Fe-Ti oxides. The dark greenish amphibole phenocrysts are sometimes pseudomorphosed or enclosed with fine-grained Fe-Ti oxides. Apatite microcrysts are included in amphibole. Clinopyroxene phenocrysts are green or brown, with anhedral to subhedral shape, overgrown and partly replaced by Fe-Ti oxides.

\subsection{Mineral Chemistry}

\subsubsection{Clinopyroxene}

The compositions of clinopyroxene (Table 1) fall in the fields of the hedenbergite $\left(\mathrm{Wo}_{45-46} \mathrm{En}_{3-3}\right)$. These compositions (Table 1$)$ are similar in peralkaline and metaluminous rhyolites, with relatively high $\mathrm{CaO}$ contents (up to $18.8 \mathrm{wt} \%$ ).

\subsubsection{Amphibole}

Amphibole phenocrysts are Na-rich phases $\left(\mathrm{Na}_{2} \mathrm{O}\right.$ : up to $\left.9.14 \mathrm{wt} \%\right)$, classified as arfvedsonite $\left(\mathrm{mg} \#<0.5 ; \mathrm{Al}^{\mathrm{VI}}<\mathrm{Fe}^{3+}\right)$; according to the nomenclature of [8]. These amphibole phenocrysts (Table 2 ) are characterized by the relatively high amount of F (up to $2.6 \mathrm{wt} \%$ ). 
C. A. Lagmet et al.

Table 1. Representative chemical analyses of clinopyroxene from Hadjer el Hamis rhyolites.

\begin{tabular}{cccc}
\hline & $\mathrm{E} 1$ & $\mathrm{E} 1$ & $\mathrm{E} 1$ \\
\hline $\mathrm{SiO}_{2}(\mathrm{wt} \%)$ & 47.19 & 47.67 & 47.15 \\
$\mathrm{TiO}_{2}$ & 0.00 & 0.00 & 0.02 \\
$\mathrm{Al}_{2} \mathrm{O}_{3}$ & 0.08 & 0.15 & 0.18 \\
$\mathrm{FeO}^{*}$ & 29.34 & 29.66 & 28.88 \\
$\mathrm{MnO}$ & 1.45 & 1.49 & 1.44 \\
$\mathrm{MgO}$ & 0.78 & 0.87 & 0.87 \\
$\mathrm{CaO}$ & 18.64 & 18.12 & 18.82 \\
$\mathrm{Na}{ }_{2} \mathrm{O}$ & 1.23 & 1.10 & 0.93 \\
$\mathrm{Total}$ & 98.73 & 99.07 & 98.27 \\
$\mathrm{Wo}(\%)$ & 46.02 & 43.77 & 45.35 \\
$\mathrm{En}$ & 3.04 & 3.26 & 3.26 \\
$\mathrm{Fs}$ & 50.93 & 52.97 & 51.39 \\
$\mathrm{Q}$ & 1.706 & 1.742 & 1.765 \\
$\mathrm{~J}$ & 0.198 & 0.177 & 0.150 \\
\hline
\end{tabular}

$\mathrm{FeO}^{*}$ : Total Fe.

Table 2. Representative chemical analyses of amphibole from Hadjer el Hamis rhyolites.

\begin{tabular}{|c|c|c|}
\hline & E1 & E3 \\
\hline $\mathrm{SiO}_{2}(\mathrm{Wt} \%)$ & 49.71 & 48.83 \\
\hline $\mathrm{TiO}_{2}$ & 0.01 & 0.11 \\
\hline $\mathrm{Al}_{2} \mathrm{O}_{3}$ & 0.44 & 0.45 \\
\hline $\mathrm{FeO}^{*}$ & 26.40 & 33.40 \\
\hline $\mathrm{MnO}$ & 0.88 & 1.16 \\
\hline $\mathrm{MgO}$ & 5.62 & 0.50 \\
\hline $\mathrm{CaO}$ & 3.45 & 1.33 \\
\hline $\mathrm{Na}_{2} \mathrm{O}$ & 8.07 & 9.14 \\
\hline $\mathrm{K}_{2} \mathrm{O}$ & 0.98 & 1.26 \\
\hline $\mathrm{BaO}$ & 0.02 & 0.14 \\
\hline $\mathrm{SrO}$ & 0.00 & 0.00 \\
\hline $\mathrm{F}$ & 2.64 & 2.57 \\
\hline $\mathrm{Cl}$ & 0.00 & 0.04 \\
\hline Total & 98.22 & 98.93 \\
\hline $\mathrm{Al}^{\text {iv }}$ (a.p.f.u) & 0.07 & 0.03 \\
\hline $\mathrm{Al}^{\mathrm{vi}}$ & 0.02 & 0.06 \\
\hline $\mathrm{Ti}$ & 0.00 & 0.00 \\
\hline $\mathrm{Fe}^{3+}$ & 0.17 & 0.15 \\
\hline $\mathrm{Fe}^{2+}$ & 3.36 & 4.50 \\
\hline $\mathrm{Mg}$ & 0.29 & 0.02 \\
\hline
\end{tabular}




\subsubsection{Feldspar}

In the rhyolites of Hadjer el Hamis, alkali feldspars are ubiquitous and show three main groups, separated by considerable gaps: nearly pure albite $\left(\mathrm{Ab}_{99-98}\right)$, anorthoclase-Na-sanidine $\left(\mathrm{Or}_{35} \mathrm{Ab}_{64}\right)$ and nearly pure sanidine $\left(\mathrm{Or}_{86}\right)$. These anorthoclase and sanidine cristals, analyzed from the Hadjer el Hamis rhyolites are characterized with low $\mathrm{BaO}(<0.10 \mathrm{wt} \%)$ and low $\mathrm{SrO}(<0.07 \mathrm{wt} \%)$ contents (Table 3).

\subsubsection{Fe-Ti Oxides and Hydroxides}

The ilmenite crystals $\left(\mathrm{TiO}_{2}: 51.5 \mathrm{wt} \%\right.$ - $52.1 \mathrm{wt} \%$ ) occur with the $\mathrm{FeO}$ and $\mathrm{MnO}$ contents reaching $45.7 \mathrm{wt} \%$ and $3.7 \mathrm{wt} \%$ respectively (Table 4). Some FeO-rich hydroxides (FeO: up to 64.9 wt\%; OH: 28.4 wt\% - 53.9 wt\%), which could be considered as limonite are present in the core of the destabilized clinopyroxene and around the F-arfvedsonite phenocrysts. Magnetite crystals (FeO: up to 86.6 $\mathrm{wt} \%$; $\mathrm{MnO}:<0.1 \mathrm{wt} \%)$ are present, generally around or inside the destabilized clinopyroxene and amphibole.

\subsection{Geochemistry}

Major-elements compositions of metaluminous rhyolite from Hadjer el Hamis are more or less similar to those of the peralkaline rhyolites (see Table 5), except that, $\mathrm{CaO}$ and $\mathrm{Na}_{2} \mathrm{O}$ contents decrease in metaluminous rhyolite. $\mathrm{SiO}_{2}, \mathrm{TiO}_{2}$, $\mathrm{Al}_{2} \mathrm{O}_{3}, \mathrm{Fe}_{2} \mathrm{O}_{3}, \mathrm{MnO}$ contents are roughly constant from peralkaline to metaluminous rhyolites.

Except the slightly enrichment of $\mathrm{Rb}$ content from peralkaline ( $\sim 56.8 \mathrm{wt} \%)$ to

Table 3. Representative chemical analyses of feldspar from Hadjer el Hamis rhyolites.

\begin{tabular}{|c|c|c|c|c|}
\hline & $\mathrm{E} 1$ & E1 & E3 & E3 \\
\hline $\mathrm{SiO}_{2}(\mathrm{wt} \%)$ & 65.67 & 67.82 & 67.82 & 67.75 \\
\hline $\mathrm{TiO}_{2}$ & 0.02 & 0.02 & 0.02 & 0.00 \\
\hline $\mathrm{Al}_{2} \mathrm{O}_{3}$ & 18.31 & 15.99 & 15.99 & 14.99 \\
\hline $\mathrm{FeO}^{*}$ & 0.45 & 0.30 & 0.30 & 0.79 \\
\hline $\mathrm{MnO}$ & 0.00 & 0.00 & 0.00 & 0.10 \\
\hline $\mathrm{MgO}$ & 0.00 & 0.00 & 0.00 & 0.00 \\
\hline $\mathrm{CaO}$ & 0.03 & 0.07 & 0.07 & 0.04 \\
\hline $\mathrm{Na}_{2} \mathrm{O}$ & 7.90 & 13.39 & 14.39 & 1.32 \\
\hline $\mathrm{K}_{2} \mathrm{O}$ & 6.58 & 0.12 & 0.12 & 13.42 \\
\hline $\mathrm{SrO}$ & 0.01 & 0.06 & 0.06 & 0.04 \\
\hline $\mathrm{BaO}$ & 0.07 & 0.09 & 0.09 & 0.00 \\
\hline Total & 99.04 & 97.84 & 98.84 & 98.46 \\
\hline Or (\%) & 35.29 & 0.79 & 0.65 & 86.80 \\
\hline $\mathrm{Ab}$ & 64.60 & 98.91 & 99.18 & 13.09 \\
\hline An & 0.14 & 0.30 & 0.30 & 0.23 \\
\hline
\end{tabular}


Table 4. Representative chemical analyses of oxides and hydroxides from Hadjer el Hamis rhyolites.

\begin{tabular}{cccccccc}
\hline & $\mathrm{E} 3$ & $\mathrm{E} 3$ & $\mathrm{E} 3$ & $\mathrm{E} 3$ & $\mathrm{E} 1$ & $\mathrm{E} 1$ & $\mathrm{E} 1$ \\
\hline $\mathrm{SiO}_{2}(\mathrm{wt} \%)$ & 0.00 & 0.90 & 0.89 & 0.08 & 0.02 & 0.00 & 0.00 \\
$\mathrm{TiO}_{2}$ & 0.02 & 0.01 & 0.03 & 0.01 & 51.51 & 52.05 & 0.00 \\
$\mathrm{Al}_{2} \mathrm{O}_{3}$ & 0.02 & 0.36 & 0.16 & 0.05 & 0.00 & 0.00 & 0.00 \\
$\mathrm{FeO}^{*}$ & 60.12 & 64.95 & 43.46 & 56.30 & 44.71 & 45.69 & 53.10 \\
$\mathrm{MnO}$ & 4.21 & 2.72 & 0.50 & 7.46 & 2.97 & 2.21 & 4.08 \\
$\mathrm{MgO}$ & 1.94 & 1.83 & 0.04 & 1.65 & 0.00 & 0.01 & 0.00 \\
$\mathrm{CaO}$ & 1.09 & 0.50 & 0.16 & 0.75 & 0.10 & 0.05 & 0.13 \\
$(\mathrm{OH})$ & 32.51 & 28.45 & 53.96 & 33.58 & 0.16 & 0.00 & 41.92 \\
$\mathrm{Total}$ & 99.90 & 99.74 & 99.20 & 99.89 & 99.46 & 100.01 & 99.22 \\
\hline
\end{tabular}

Table 5. Major and trace elements for peralkaline and metaluminous rhyolites from Hadjer el Hamis (Lake Chad basin).

\begin{tabular}{|c|c|c|c|}
\hline & E1 & E2 & E3 \\
\hline $\mathrm{SiO}_{2}(\mathrm{wt} \%)$ & 70.85 & 70.23 & 70.74 \\
\hline $\mathrm{TiO}_{2}$ & 0.30 & 0.30 & 0.30 \\
\hline $\mathrm{Al}_{2} \mathrm{O}_{3}$ & 12.72 & 12.56 & 12.49 \\
\hline $\mathrm{Fe}_{2} \mathrm{O}_{3}{ }^{*}$ & 4.42 & 4.40 & 4.19 \\
\hline $\mathrm{MnO}$ & 0.13 & 0.14 & 0.14 \\
\hline $\mathrm{MgO}$ & 0.08 & 0.06 & 0.08 \\
\hline $\mathrm{CaO}$ & 0.57 & 0.63 & 0.74 \\
\hline $\mathrm{Na}_{2} \mathrm{O}$ & 5.09 & 4.49 & 3.98 \\
\hline $\mathrm{K}_{2} \mathrm{O}$ & 4.99 & 4.94 & 4.93 \\
\hline $\mathrm{P}_{2} \mathrm{O}_{5}$ & 0.03 & 0.03 & 0.02 \\
\hline LOI & 0.60 & 2.00 & 2.20 \\
\hline Total C & 0.08 & 0.40 & 0.30 \\
\hline Total & 99.77 & 99.75 & 99.79 \\
\hline P.I. & 1.08 & 1.01 & 0.95 \\
\hline D.I. & 5.26 & 4.00 & 5.52 \\
\hline $\mathrm{Be}(\mathrm{ppm})$ & 4 & $<1$ & 2 \\
\hline $\mathrm{Rb}$ & 56.8 & 58.6 & 65.5 \\
\hline Cs & 0.2 & 0.2 & 0.2 \\
\hline $\mathrm{Ba}$ & 280 & 251 & 240 \\
\hline $\mathrm{Sr}$ & 23.4 & 16.4 & 15.8 \\
\hline $\mathrm{V}$ & 9 & 8 & $<8$ \\
\hline $\mathrm{Ni}$ & 0.9 & 0.4 & 0.2 \\
\hline $\mathrm{Cr}$ & $<20$ & 30 & $<20$ \\
\hline Co & 1.4 & 1.3 & 0.6 \\
\hline $\mathrm{Cu}$ & 2.3 & 0.9 & 1.1 \\
\hline $\mathrm{Cd}$ & 0.3 & 0.4 & 0.3 \\
\hline
\end{tabular}




\section{Continued}

\begin{tabular}{|c|c|c|c|}
\hline $\mathrm{Zn}$ & 59 & 150 & 143 \\
\hline $\mathrm{Pb}$ & 7.0 & 3.8 & 4.8 \\
\hline Mo & 4.0 & 0.5 & 0.9 \\
\hline $\mathrm{Ga}$ & 33.3 & 33.1 & 31.6 \\
\hline Sn & 13.0 & 7.0 & 4.0 \\
\hline $\mathrm{W}$ & 0.9 & 0.8 & 0.6 \\
\hline $\mathrm{Bi}$ & 33.3 & 33.1 & 31.6 \\
\hline $\mathrm{Ta}$ & 4.7 & 4.9 & 4.4 \\
\hline $\mathrm{Nb}$ & 76.2 & 84.8 & 79.2 \\
\hline Th & 8.8 & 9.7 & 8.0 \\
\hline $\mathrm{U}$ & 2.2 & 2.2 & 1.8 \\
\hline $\mathrm{Zr}$ & 523 & 586 & 519 \\
\hline $\mathrm{Hf}$ & 12.7 & 13.7 & 13.0 \\
\hline $\mathrm{Y}$ & 54.9 & 57.0 & 52.2 \\
\hline $\mathrm{La}$ & 71.2 & 78.7 & 71.8 \\
\hline $\mathrm{Ce}$ & 152.4 & 163.2 & 146.1 \\
\hline $\operatorname{Pr}$ & 16.86 & 18.76 & 15.87 \\
\hline $\mathrm{Nd}$ & 63.6 & 69 & 60 \\
\hline $\mathrm{Sm}$ & 12.96 & 14.34 & 12.12 \\
\hline $\mathrm{Eu}$ & 2.46 & 2.35 & 2.13 \\
\hline $\mathrm{Gd}$ & 12.38 & 12.96 & 11.84 \\
\hline $\mathrm{Tb}$ & 1.83 & 1.98 & 1.78 \\
\hline Dy & 10.93 & 10.95 & 9.98 \\
\hline Ho & 2.02 & 2.11 & 2.04 \\
\hline Er & 5.47 & 5.79 & 5.09 \\
\hline $\mathrm{Tm}$ & 0.77 & 0.84 & 0.76 \\
\hline $\mathrm{Yb}$ & 5.3 & 5.13 & 4.88 \\
\hline $\mathrm{Lu}$ & 0.68 & 0.77 & 0.7 \\
\hline$\Sigma \mathrm{REE}$ & 359 & 387 & 345 \\
\hline $\mathrm{Ga} / \mathrm{Al}$ & 4.95 & 4.98 & 4.78 \\
\hline $\mathrm{Y} / \mathrm{Nb}$ & 0.72 & 0.67 & 0.66 \\
\hline $\mathrm{Rb} / \mathrm{Nb}$ & 0.75 & 0.69 & 0.83 \\
\hline $\mathrm{Sc} / \mathrm{Nb}$ & 0.01 & 0.01 & 0.03 \\
\hline $\mathrm{Zr} / \mathrm{Nb}$ & 6.87 & 6.91 & 6.55 \\
\hline $\mathrm{Rb} / \mathrm{Sr}$ & 2.43 & 3.57 & 4.15 \\
\hline $\mathrm{Rb} / \mathrm{Ba}$ & 0.20 & 0.23 & 0.27 \\
\hline $\mathrm{K} / \mathrm{Rb}$ & 730 & 700 & 625 \\
\hline $\mathrm{Eu} / \mathrm{Eu}^{\star}$ & 0.59 & 0.53 & 0.54 \\
\hline$(\mathrm{La} / \mathrm{Yb}) \mathrm{N}$ & 9.1 & 10.4 & 10.0 \\
\hline
\end{tabular}

$\mathrm{Fe}_{2} \mathrm{O}_{3}{ }^{*}$ : Total Fe as $\mathrm{Fe}^{3+}$; L.O.I.: Loss on ignition; D.I.: Differentiation index; P.I.: Peralkaline index; D.L.: Detection limit. 
metaluminous (65.5 wt\%), the composition of the studied rocks are more or less similar. Whereas $\mathrm{Ba}, \mathrm{Sr}$ and $\mathrm{Y}$ contents are low.

The total REE concentrations ranging from 359 - $387 \mathrm{ppm}$ to $345 \mathrm{ppm}$, respectively from peralkaline to metaluminous rhyolites. Overall, peralkaline and metaluminous rhyolites from the Lake Chad basin exhibit the similar $\mathrm{Zr} / \mathrm{Nb}$ ratios (see Table 5), just below 7 ( $\mathrm{Zr} / \mathrm{Nb}$ : 6.5 - 6.9).

Primitive mantle-normalized [9] REE (Rare Earth Elements) patterns for all samples are subparallel (Figure 4). The rhyolites from the Lake Chad basin exhibit high enrichment in LREE and display fractionated REE pattern with $(\mathrm{La} / \mathrm{Yb})_{\mathrm{N}}$ ratios ranging from 9.1 to 10.4 .

The REE patterns (Figure 4) show negative $\mathrm{Eu}$ anomalies, with $\mathrm{Eu} / \mathrm{Eu}^{*}$ $\left(\mathrm{Eu} / \mathrm{Eu}^{*}=\mathrm{Eu}_{\mathrm{N}} / \sqrt{\left(\mathrm{Sm}_{\mathrm{N}} \times \mathrm{Gd}_{\mathrm{N}}\right)}\right)$ ranging from 0.53 to 0.59 , which may indicate removal of feldspar by crystal fractionation. Primitive mantle-normalized [9] multi-element patterns (Figure 5) show negative $\mathrm{Ba}, \mathrm{P}, \mathrm{Sr}$ and $\mathrm{Ti}$ anomalies.

\section{Discussion}

\subsection{Petrological Implications}

The peralkaline and metaluminous rhyolitic magmas from Lake Chad basin derive likely from the same source, according to their coexistence in the same dome (Hadjer el Hamis) and their similar $\mathrm{Zr} / \mathrm{Nb}$ ratios. According to the $\mathrm{Y}$ vs $\mathrm{Nb}$ diagram (Figure 6), the silicic rocks of the Lake Chad are from within plate domain and likely the product of the intraplate magmatism [2]. The values of $\mathrm{K} / \mathrm{Rb}, \mathrm{Rb} / \mathrm{Sr}$, $\mathrm{Rb} / \mathrm{Ba}$ and $\mathrm{Ga} / \mathrm{Al}$ ratios (see Table 5; Figure 6) for the Lake Chad rhyolites are similar to those exhibited for the A-type granite [10]. A-type granites ([11] [12] [13]) are generated in association with uplift and major strike-slip faulting.

Primary diversity in source rocks, varying amounts of extraction of an earlier melt phase, or tectonic juxtaposition can be suggested as causes of magma heterogeneity [6].

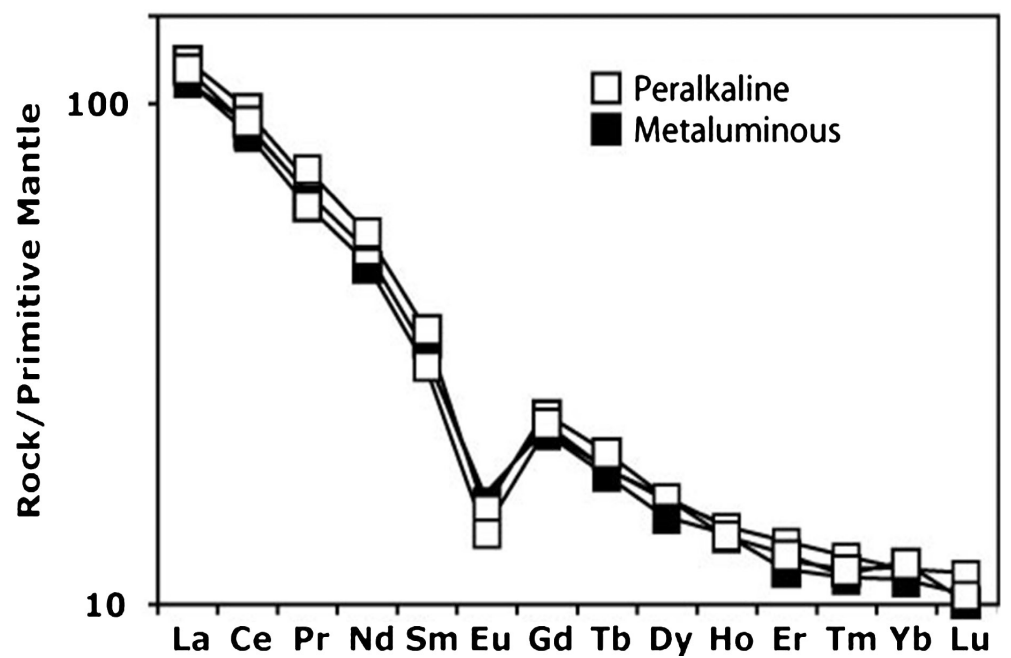

Figure 4. Primitive mantle-normalized [9] REE diagrams for rhyolites from Hadjer el Hamis. 


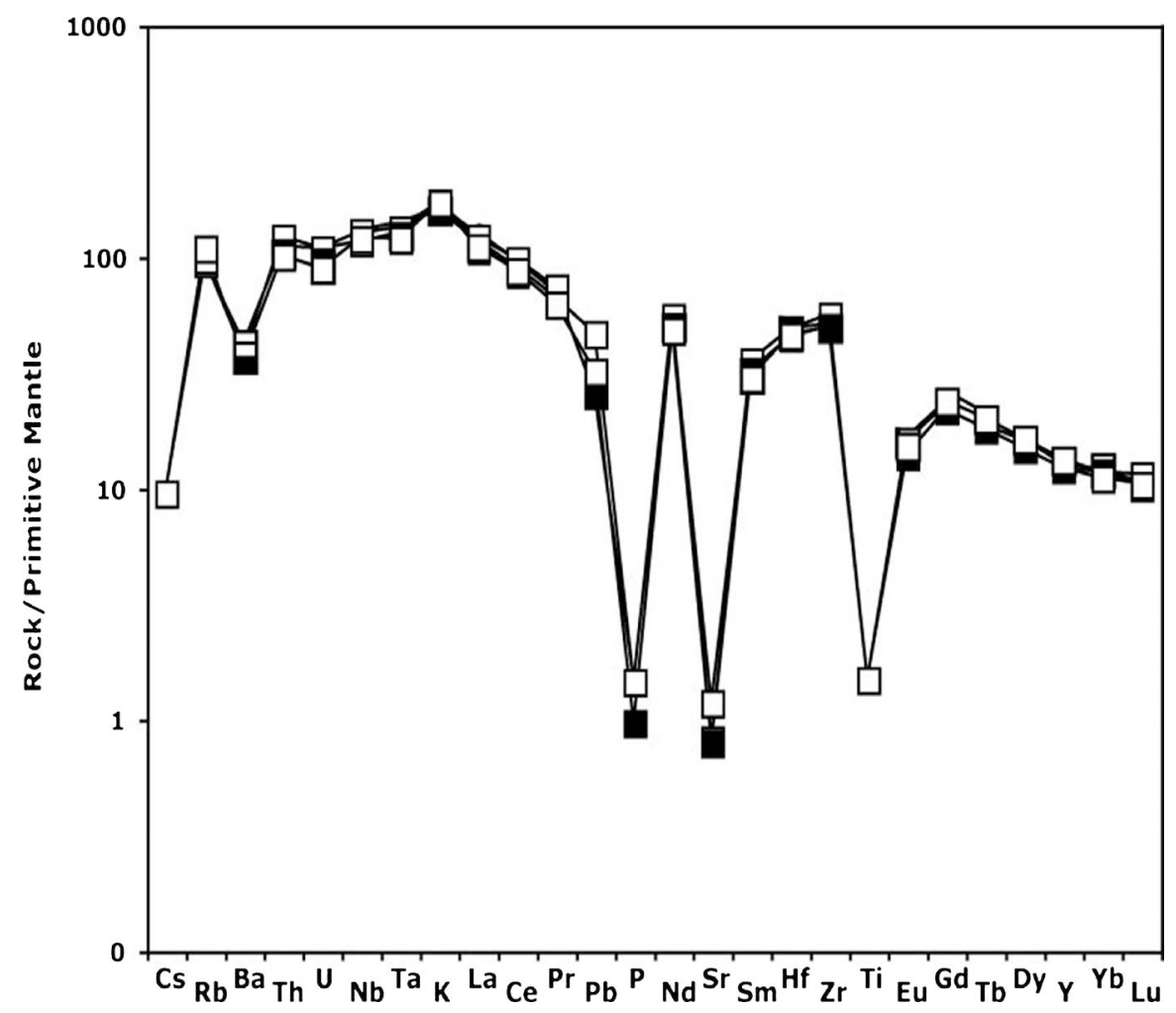

Figure 5. Primitive mantle-normalized [9] multi-element diagrams for rhyolites from Hadjer el Hamis.
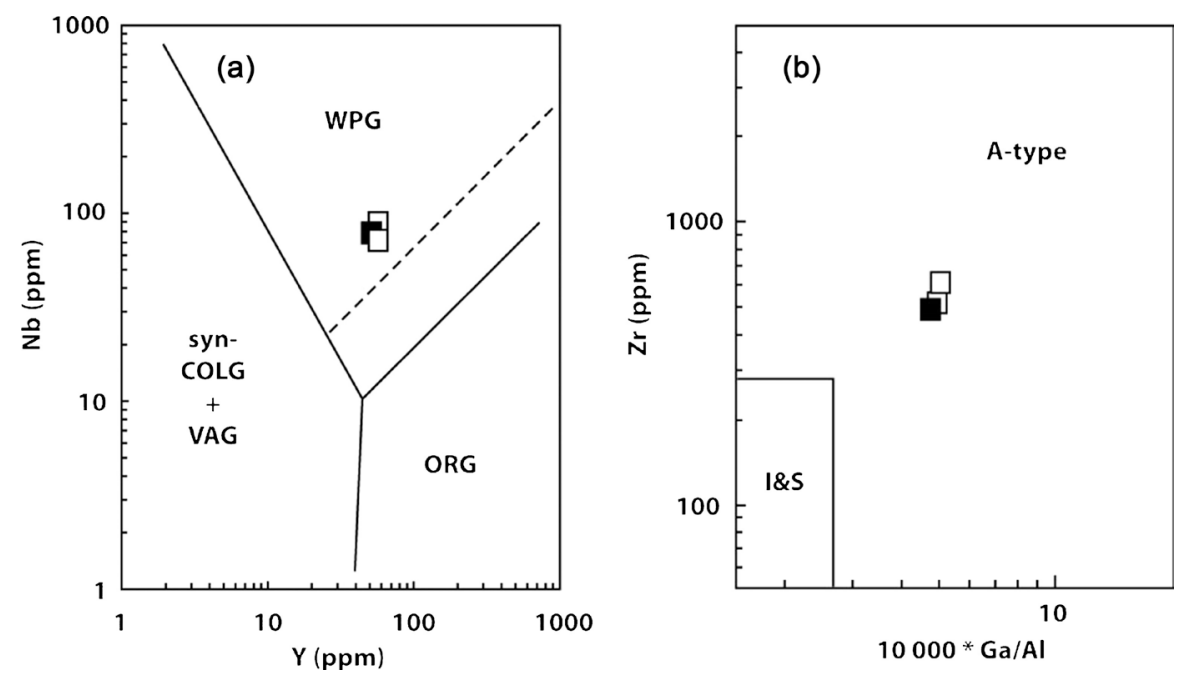

Figure 6. Composition of rhyolites from SE Lake Chad in $\mathrm{Y}$ vs $\mathrm{Nb}$ (a) and $\mathrm{Ga} / \mathrm{Al}$ vs $\mathrm{Zr}$ (b) diagrams.

However, other processes such as different degrees of partial melting or removal of successive batches of magma from a suitable source might also produce ranges of subalkaline to peralkaline magmas. Indeed, the trace-element variations of the Lake Chad rhyolites suite, such as subparallel primitive mantle-normalized REE and multi-element patterns, indicate that they are likely the cogenetic products. 


\subsection{Crystallization Process}

The occurrence of nearly pure albite and sanidine are regarded as reflecting alkali exchange during sub-solidus hydrothermal reactions or as corresponding to late-stage recrystallization at hydrothermal conditions [4]. Quartz phenocrysts with corrosion gulfs were probably generated during ascent to the surface upon eruption, during decompression of the rhyolitic magmas.

The destabilization of hedenbergite phenocrysts core, breaking down into limonite and ilmenite, was probably caused by a sudden increasing of $\mathrm{fO}_{2}$ in silicic magmas, triggered from a hydrothermal process, associated with Fand alkali-bearing fluids influx; which promoted the enrichment of $\mathrm{Na}$ in the hedenbergite rims and the crystallization of arfvedsonite. This hydrothermal process accompanied by an influx of F- and alkali-rich fluids is evidenced by the presence of F-arfvedsonite and the Na-rich phases such as pure albite. Thus, the presence of limonite, in addition to showing variable water content, frequently have other elements reported due to the intimate mixture of the hydrous iron oxides with colloidal silica, as well as small of hydrous aluminum oxides.

The occurrence of phases such as arfvedsonite (K, Ba, Ti), ilmenite (Ti), apatite $(\mathrm{P})$ and alkali feldspar $(\mathrm{K}, \mathrm{Sr}, \mathrm{Eu})$ in the rhyolitic lavas from Lake Chad basin are consistent with the well-developed negative $\mathrm{Ba}, \mathrm{P}, \mathrm{Sr}, \mathrm{Ti}$ and $\mathrm{Eu}$ anomalies. The oxygen fugacity of melts, the minerals in fractional process and the stability of minerals in the magma system ([14] [15] [16] [17]) are sometime affected by the halogen-rich fluids such as $\mathrm{F}$ and $\mathrm{Cl}$. As described for the destabilization of hedenbergite from the Lake Chad rhyolites, hydrothermal fluids can react with pre-existing minerals ([18] [19] [20]) to generate others (i.e. arfvedsonite, limonite).

\section{Conclusion}

The metaluminous rhyolites from Hadjer el Hamis are characterized by the occurrence of phases such as arfvedsonite, hedenbergite, ilmenite and alkali feldspar consistent with the well-developed negative $\mathrm{Ba}, \mathrm{P}, \mathrm{Sr}, \mathrm{Ti}$ and $\mathrm{Eu}$ anomalies. The occurrence of nearly pure albite and sanidine is regarded as reflecting alkali exchange during sub-solidus hydrothermal reactions or as corresponding to late-stage recrystallization at hydrothermal conditions. Indeed, the studied metaluminous rhyolites are from within plate domain and likely the product of the intraplate magmatism. According to their coexistence in the same dome with peralkaline rhyolites and their similar $\mathrm{Zr} / \mathrm{Nb}$ ratios these rocks are from the same source (cogenetic). The heterogeneity of the rhyolitic lavas (metaluminous and peralkaline) from Hadjer el Hamis could be linked to the destabilization of hedenbergite phenocrysts core, breaking down into limonite and ilmenite, which involved a sudden increasing of $\mathrm{fO}_{2}$ in silicic magmas and promoted the enrichment of $\mathrm{Na}$ in the hedenbergite rims; and the crystallization of arfvedsonite and the Na-rich phases such as pure albite. These therefore cause the decreasing of $\mathrm{Na}_{2} \mathrm{O}$ contents in the magma source and the generation of metalu- 
minous A-type rhyolite.

\section{Acknowledgements}

The TWAS organization is acknowledged for providing a grant to G.I.B.M. for five months stay in Brazil in the Geosciences Institute, University of Brasilia (UnB).

\section{Conflicts of Interest}

The authors declare no conflicts of interest regarding the publication of this paper.

\section{References}

[1] Eby, G.N. (1992) Chemical Subdivision of the A-Type Granitoids: Petrogenetic and Tectonic Implications. Geology, 20, 641-644. https://doi.org/10.1130/0091-7613(1992)020<0641:CSOTAT>2.3.CO;2

[2] Mbowou, G.I.B., Botelho, N.F., Lagmet, C. and Ngounouno, I. (2015) Petrology of Peraluminous and Peralkaline Rhyolites from the SE Lake Chad (Northernmost Cameroon Line). Journal of African Earth Sciences, 112, 129-141. https://doi.org/10.1016/j.jafrearsci.2015.09.015

[3] Vicat, J.-P., Pouclet, A., Bellion, Y. and Doumnang, J.-C. (2002) Les rhyolites hyperalcalines (pantellérites) du lac Tchad. Composition et signification tectonomagmatique. Comptes rendus Geoscience, 334, 886-891. https://doi.org/10.1016/S1631-0713(02)01832-1

[4] Mbowou, G.I.B., Lagmet, C., Nomade, S., Ngounouno, I., Déruelle, B. and Ohnenstetter, D. (2012) Petrology of the Late Cretaceous Peralkaline Rhyolites (Pantellerite, Comendite) from Lake Chad. Journal of Geosciences, 57, 127-141. https://doi.org/10.3190/jgeosci.118

[5] Moreau, C., Regnoult, J.-M., Déruelle, B. and Robineau, B. (1987) A New Tectonic Model for the Cameroon Line, Central Africa. Tectonophysics, 139, 317-334. https://doi.org/10.1016/0040-1951(87)90206-X

[6] Hong, W., Xu, X. and Zou, H. (2013) Petrogenesis of Coexisting High-Silica Aluminous and Peralkaline Rhyolites from Yunshan (Yongtai), Southeastern China. Journal of Asian Earth Sciences, 74, 316-329. https://doi.org/10.1016/j.jseaes.2013.01.005

[7] Le Bas, M.J., Le Maitre, R.W., Streckeisen, A. and Zanettin, B. (1986) A Chemical Classification of Volcanic Rocks Based on the Total Alkali-Silica Diagram. Journal of Petrology, 27, 745-750. https://doi.org/10.1093/petrology/27.3.745

[8] Leake, B.E., et al. (1997) Nomenclature of Amphiboles: Report of the Subcommitee on Amphiboles of the International Mineralogical Association Commission on New Minerals and Mineral Names. Mineralogical Magazine, 61, 295-321. https://doi.org/10.1180/minmag.1997.061.405.13

[9] McDonough, W.F. and Sun, S.-S. (1995) The Composition of the Earth. Chemical Geology, 120, 223-253. https://doi.org/10.1016/0009-2541(94)00140-4

[10] Whalen, J.B., Currie, K.L. and Chappell, B.W. (1987) A-Type Granites: Geochemical Characteristics, Discrimination and Petrogenesis. Contributions to Mineralogy and Petrology, 9, 407-419. https://doi.org/10.1007/BF00402202

[11] Loiselle, M.C. and Wones, D.R. (1979) Characteristics of Anorogenic Granites. 
Geological Society of America, Abstracts with Programs, 11, 468.

[12] Collins, W.J., Beams, S.D., White, A.J.R. and Chappell, B.W. (1982) Nature and Origin of A-Type Granites with Particular Reference to Southeastern Australia. Contributions to Mineralogy and Petrology, 80, 189-200.

https://doi.org/10.1007/BF00374895

[13] White, A.J.R. and Chappell, B.W. (1983) Granitoid Types and Their Distribution in the Lachlan Fold Belt, Southeastern Australia. Geological Society of America Me moirs, 159, 21-34. https://doi.org/10.1130/MEM159-p21

[14] Qiu, J.S., Wang, D.Z., McInnes, B.I.A., Jiang, S.Y., Wang, R.C. and Kanisawa, S. (2004) Two Subgroups of A-Type Granites in the Coastal Area of Zhejiang and Fujian Provinces, SE China: Age and Geochemical Constraints on Their Petrogenesis. Transactions of the Royal Society of Edinburgh: Earth Sciences, 95, 227-236. https://doi.org/10.1017/S0263593300001036

[15] Scaillet, B. and Macdonald, R. (2001) Phase Relations of Peralkaline Silicic Magmas and Petrogenetic Implications. Journal of Petrology, 42, 825-845. https://doi.org/10.1093/petrology/42.4.825

[16] Scaillet, B. and Macdonald, R. (2003) Experimental Constraints on the Relationships between Peralkaline Rhyolites of the Kenya Rift Valley. Journal of Petrology, 44, 1867-1894. https://doi.org/10.1093/petrology/egg062

[17] Carlo, I.D., Rotolo, S.G., Scaillet, B., Vincenzo, B. and Pichavant, M. (2010) Phase Equilibrium Constraints on Pre-Eruptive Conditions of Recent Felsic Explosive Volcanism at Pantelleria Island, Italy. Journal of Petrology, 51, 2245-2276. https://doi.org/10.1093/petrology/egq055

[18] Marks, M. and Markl, G. (2001) Fractionation and Assimilation Processes in the Alkaline Augite Syenite Init of the Ilímaussaq Intrusion, South Greenland, as Deduced from Phase Equilibria. Journal of Petrology, 42, 1947-1969. https://doi.org/10.1093/petrology/42.10.1947

[19] Markl, G., Marks, M.A.W. and Frost, B.R. (2010) On the Controls of Oxygen Fugacity in the Generation and Crystallization of Peralkaline Melts. Journal of Petrology, 51, 1834-1847. https://doi.org/10.1093/petrology/egq040

[20] Schönenberger, J., Marks, M., Wagner, T. and Markl, G. (2006) Fluid-Rock Interaction in Autoliths of Agpaitic Nepheline Syenites in the Ilímaussaq Intrusion, South Greenland. Lithos, 91, 331-351. https://doi.org/10.1016/j.lithos.2006.03.024 